\title{
EQUAL OpPoRTUNity, Market Preference ANd Voter TuRnOUT: An ANALYSIS OF THE 1996, 2000, AND 2004 U.S. Presidential Elections
}

\author{
RoBert Hughes \\ University of Kansas
}

This article examines how the American political tradition both constrains and enables voter turnout in United States presidential elections. Specifically I examine the impact of the American Creed, defined as the intersection of beliefs in equal opportunity, market preference, and individual responsibility, on voter turnout. Using data from the 1996, 2000, and 2004 American National Election Surveys, I develop a unified vote choice model and test it using multinomial logistic regression. While the idea that people will choose to vote when they feel strongly about an issue or value is intuitive, my findings show that the American Creed acts as "master frame," or "lens," that both constrains and enables turnout by limiting the "acceptable" motivations to vote. Specifically, I find that support for equality increases Democratic turnout but has no effect on Republican turnout. Similarly, support for market preferences increases Republican turnout but has no effect on Democratic turnout. I close with a discussion of the implications on the health of U.S. democracy, and the importance of including the choice of abstention in voting behavior research.

\footnotetext{
${ }^{1}$ An earlier version of this paper was presented at the 2009 annual meeting of the Midwest Sociological Society. I would like to thank Meredith Kleykamp, David N. Smith, William Jacoby, Eric Hanley, and Michael Lynch, as well as the reviewers, for their valuable comments and suggestions on earlier drafts of this paper. ${ }^{2}$ Robert Hughes is a Ph.D. student at the University of Kansas. All inquiries should be sent to the Department of Sociology, University of Kansas, Fraser Hall, Rm. 713, 1415 Jayhawk Boulevard, Lawrence, KS 66045, or emailed to maxweber@ku.edu.
} 
Attitudes about equality are of central importance to democracy, and while their influence on perceptions of social policy and vote choice is well studied, their influence on voter turnout remains under examined. In the United States, political opinions are commonly framed around three themes, namely equal opportunity, individual responsibility and market preferences (Kinder and Sanders 1996; Lipset 1983; Lipset 1996; Sears, Sidanius, and Bobo 2000) (See also, Gilens 1999; Sidanius, Pratto, and Bobo 1996). Support for equal opportunity is nested within this "American political tradition" (Feldman and Zaller 1992). And yet, it is within definition of "equal opportunity" that inequality finds its rhetorical defense, with individualism and market preferences playing their part (Gilens 1999; Kinder and Sanders 1996; Santa Ana 2002; Sears, Sidanius, and Bobo 2000; Sidanius, Pratto, and Bobo 1996; Welsh 2008). While a belief in the "equality of individuals" has dramatically marked the last few decades, "white support for policies that might bring such principles to life ... [has] ... not" (Kinder and Sanders 1996:270). More importantly, however, those opposed to affirmative action have pressed their attack under the banner of "equal opportunity" and "freedom from interference," artfully weaving in references to individual responsibility and market principles (Santa Ana 2002; Welsh 2008). Following Kinder and Sanders (1996). I refer to this conceptualization of equality, and its intersection with individualism and market preferences, as the "American Creed." The mercurial ability of the American Creed to provide a moral defense for equality as well as inequality allows it to be marshaled to support a vast array of political agendas and candidates across the political spectrum (Gilens 1999). Conceptualized as such, the American Creed represents an element of the American political tradition around which American political life is framed (Feldman and Zaller 1992; Laitin and Aaron 1988). This frame acts as a shared cultural referent that allows public debate within a common framework of meaning (Feldman and Zaller 1992; Laitin and Aaron 1988). But does the American Creed, as an organization of values and principles, both constrain and enable voter turnout? As part of the "American political tradition" (Feldman and Zaller 1992), does it get people to the polls? 
In this article, I argue that the value complex that makes up the American Creed is so predominant in today's society, that it has strong enabling and constraining influences on voter turnout. Specifically, my findings show that individuals tend to go the polls to support elements of the American Creed, and those attitudes and opinions that are not consistent with any one element of the Creed are reorganized within attitudinal frameworks that do not directly challenge any element of Creed. To develop and defend this position, I discuss American beliefs about equality and the organization of political attitudes in the United States. In doing so, I develop a set of testable hypotheses concerning patterns of attitudinal framework efficacy suggested by the literature. To test these hypotheses, I use data from the 1996, 2000, and 2004 American National Election Survey, to develop, and estimate, a unified vote choice model using multinomial logistic regression. Following Lacy and Burden (1999), I utilize a trichotomous dependent variable, consisting of voted Democrat, voted Republican, and did not vote. I use the unified vote choice model, with a trichotomous dependent variable, because the exclusion of abstention, and the aggregation of all voters into a single category, often leads to erroneous conclusions (Lacy and Burden 1999; Lacy and Monson 2002). I then present my findings, which suggest, given the literature on beliefs about equality, that individuals tend to vote for values in the American Creed, and that attitudinal positions that directly oppose these values do not raise turnout for either party. While the different aspects of the Creed are embraced at different levels by individuals, attitudinal positions that are inconsistent with an element of the American Creed are reorganized into an alternative attitudinal framework, making these views less contradictory with the ideas of "equal opportunity," "individual responsibility," and "market preferences." Thus, my findings suggest that the American Creed acts as "master frame," or "lens," that both constrains and enables turnout by limiting the "acceptable" motivations to vote. I discuss the broader implications of the efficacy of the American Creed in the conclusion. 


\section{Mass Belief Systems and Attitudes about Equality}

Beliefs about Equality, and the American Creed

The American Creed represents a complex of values that sit at the center of American political life. Myrdal, Sterner and Rose (1944:1xix), described the American Creed as, "high national and Christian precepts." While this definition is certainly antiquated, the idea of an American Creed is still a useful concept. Feldman and Zaller (1992:292) argue that "most Americans can draw... upon several elements of the American political tradition," and the literature on beliefs about equality point to three key themes that make up a contemporary American Creed. The first key aspect of the American Creed is the support for "free markets" and a suspicion of government regulation (Kinder and Sanders 1996). The second aspect is a belief in equal opportunity, and the third belief is that the individual is responsible for themselves (Kinder and Sanders 1996; Kluegel and Smith 1986). On the surface the American Creed is a specific version of social liberalism, but while it retains the possibility of providing a progressive attitudinal foundation for promoting equality, it also possesses a conceptual framework that can be used to justify inequality. This is its special mercurial quality. Closely associated with the idea of "equal opportunity," is a "broad preference for market criteria of 'earned desserts' rather than political remedies for inequality" (Sears, Sidanius, and Bobo 2000:114). And, from a policy perspective, even those that do support programs that promote equality tend to favor programs that promote "equal opportunity," but not programs that "impose" equal outcomes (Gilens 1999; Welsh 2008). Thus, the common U.S. conceptualization of equality, as equality of opportunity but not outcome, leaves a vast space for the development, and continuance, of actual inequality.

Like any political attitude, levels of importance an individual attaches to each of the three aspects of the American Creed varies among individuals (Dalton 2006; Fleishman 1988), but what makes the American Creed distinct is its pervasiveness in American political culture (Feldman and Zaller 1992; Kluegel and Smith 1986). While there are many sources for an individuals specific 
political values and attitude positions (Altemeyer 1996; Barker and Tinnick 2006), from a political culture perspective, the nexus of equal opportunity, market preference, and individual responsibility represents a convergence of "points of concern" (Laitin and Aaron 1988). Similar to Abramowitz and Saunders (2006), and following Jost (2006:653), I define political ideology as an "interrelated set of moral and political attitudes that possesses cognitive, affective, and motivational components." For the ideologically charged, the American Creed provides a set of values that provide a foundation for political action (Dalton 2006; Moskowitz and Jenkins 2004). For the majority who are less ideological, the values and principles of individual responsibility, equal opportunity, and market preferences act as points of reference and general orientations for those that do not utilize ideological voting (Converse 2006 [1964]; Jacoby 1995). The rhetoric surrounding social policy initiatives is all but ubiquitously connected to market preferences, equal opportunity, and individual responsibility (Santa Ana 2002). In this sense, the American Creed functions as a "general issue frame" (Jacoby 2000), within which specific issues are situated, that is utilized by both the political left and right (Kinder and Sanders 1996).

In reference to the political right, the American Creed is often utilized to defend the status quo. In their research on conservatism, Jost, Glaser, Kruglanski, and Sulloway (2003) find that the core aspects of conservatism are a general acceptance of inequality and a resistance to change. This does not mean that conservatives see themselves as endorsing inequality, but rather that it is sometimes a necessary outcome, due to laziness, lack of effort and differences in talent (Davis and Moore 2006 [1945]; Jost, Glaser, Kruglanski, and Sulloway 2003; Welsh 2008). Santa Ana (2002) develops a systematic account of the neo-conservative discourse on racism that is consistent with the Jost et al (2003) findings. As Santa Ana (2002:150) states, "Since, in their view, there are no structural reasons and foundational beliefs holding racialized minorities down, the reason why people of color do poorly is a matter of personal drive and agency....[Neo-conservatives]... accept and advocate the hegemonic values unaltered from the times when actions based on these values were the source of the original racial oppression." Thus, 
as Santa Ana (2002:125) notes earlier, "In the anti-affirmative action view, the United States is already the closest thing on Earth to a pure meritocracy.... Since affirmative action is structured to link race and gender to hiring and admission procedures, it is seen as a stricture on individual autonomy, an unacceptable governmental constriction on personal initiative."

The links between the American Creed and the acceptance of inequality are undeniable. Kinder and Sanders (1996:277), explicitly comment on these links when they state, "To its supporters, affirmative action is required to bring true equality of opportunity to life, whereas to its opponents, affirmative action, by treating some groups better than others, violates equal opportunity for individuals." Sears, Sidanius and Bobo (2000), also find that while whites generally agree about the formal equality of individuals, there are major divides on the question of how large a problem equality is in today's society. Perhaps more disturbing is the finding that even if there is more agreement about the formal equality of some groups, there is an alarming lack of support for general difference, issues of gay rights, immigration policy and other issues, that can be described as "ethnocentric" (Gilens 1999; Kinder and Sanders 1996; Kluegel and Smith 1986; Santa Ana 2002; Sears, Sidanius, and Bobo 2000). And Sears, Sidanius and Bobo (2000) provide convincing evidence that while those against affirmative action may reference a "damaging of equality of opportunity," they are decisively anti-egalitarian. Even in its most articulate, if not also naïve, libertarian form, the conservative defense of inequality relies on the American Creed for its validity and foundational precepts (Welsh 2008), and thus the American political tradition itself. Attacks on social policies that require any redistribution of resources is critiqued as "socialist," and thus an assault on individual rights, and the freedom enjoyed under the "unregulated market" (Welsh 2008). This conservative position often results in the formation of what Kluegel and Smith (1986) term the dominant ideology. This is a perspective that involves three core beliefs: "First, that opportunity for economic advancement is widespread in America today; second, that individuals are personally responsible for their positions; and third, that the overall system of inequality is, therefore, equitable 
and fair" (Kluegel and Smith 1986:23). The "dominant ideology" is then one particular type of subscription to the American Creed that ironically, almost completely, devalues equality in favor of individual "freedom."

If the American Creed can be used to defend inequality, it can also be used to further the achievement of equality of opportunity, if not outcomes. Where conservatism accepts inequality, liberalism in a sense is defined by the rejection of inequality (Kluegel and Smith 1986). While liberalism and conservatism are commonly placed at opposite ends of a shared spectrum, Kerlinger (1984) argues that liberalism and conservatism are distinct and separate in the values that they emphasize, and that liberalism places more emphasis on equality than conservatism. However, support for equality within the United States takes place in reference to, or in the shadow of, the American Creed. Martin Luther King Jr. discussed the values making up the American Creed when he referenced the "disease" that was "preventing our democratic and Christian health from being realized," and he remarked on the duality of that Creed when he claimed that "Ever since the signing of the Declaration of Independence, America has manifested a schizophrenic personality on the question of race" (Santa Ana 2002:124, 127). General Colin Powell, in his support for affirmative action at the 1996 Republican National Convention, stated that, "where discrimination still exists, or where the scars of past discrimination still contaminate and disfigure the present, we must not close out eyes to it, declare there is a level playing field, and hope that it will go away by itself. . . I I strongly support affirmative action" (Santa Ana 2002:150). These statements not only reference the American Creed, in the Powel case equality of opportunity specifically, but also show an increased commitment and emphasis to the equality of opportunity element, compared to the traditional conservative viewpoint.

Strongly emphasizing the equality aspect of the American Creed, however, does not necessarily mean a lack of emphasis on the importance of the market, or a reduced commitment to individualism. Many who support equality of opportunity also strongly emphasize individualism, and as such, demand that welfare recipients ... share a commitment to individual effort and responsibility" 
(Gilens 1999:5). Sears, Sidanius, and Bobo (2000) find, however, that as an emphasis on individualism increases, individuals are less likely to see inequality as a structural problem, and thus decrease their support for affirmative action programs. However, Gilens (1999), finds that those who oppose welfare are often still in favor of other social programs that promote equality of opportunity. The key point here is that the American Creed sits at the center of every political discussion, and is used as a rhetorical device by those on both sides of nearly every political issue (Kinder and Sanders 1996; Santa Ana 2002). Even if, in the case of conservative acceptance of inequality these are only rhetorical references to the equality of opportunity element in the American Creed, the other two elements are proposed to have equally significant influence over political life as well (Feldman and Zaller 1992). If political activity is constrained to operate within the contexts of the American Creed, then the American Creed should not simply be a framing device or cultural referent, but actually be visible in the voting process. That is, if the American Creed essentially mediates one's stance on nearly every political issue at the level suggested by the literature on beliefs about equality, then voter turnout should be driven by these beliefs in a manner consistent with the American Creed itself. The key implication is that individuals should tend to vote in support of an element of the American Creed, but not directly in support of values that blatantly contradict an element of the American Creed. Views that contradict the American Creed do not simply disappear. Rather, this outlook also expects that those who hold political views that are inconsistent with the Creed should reorganize them into an attitudinal framework that does not directly challenge this central element of the American political tradition.

\section{Theories of Attitudinal Organization}

Understanding how political attitudes and values influence turnout is directly related to their organization and the principles and values that make up the American Creed are no exception. There are three basic processes (or mechanisms) thought to link attitudes and values to political action in the literature. The traditional ap- 
proach is best described as "Ideological voting," and is defined as a process where by individuals arrive at a decision to vote based on their political opinions, which are derived deductively from their principles and values (Dalton 2006; Lavine and Gschwend 2007; Lavine, Thomsen, Zanna, and Borgida 1998). In critique, Moskowitz and Jenkins (2004:396) argue for a "multi-tiered or hierarchical framework in which respondents use heuristics, backward reasoning, and other information shortcuts to organize relatively consistent political attitudes." The hierarchical framework theory is more dynamic and sees citizens as combining principled reasoning and information to assess political issues along multiple general orientations, and thus represents an intuitive conceptual framework for the operation of the American Creed (Dalton 2006; Moskowitz and Jenkins 2004). The third perspective with strong empirical support, argues that while only a small percentage of the population may have the skills to engage in ideological voting of both these types, most people use partisanship heuristics to make political decisions and guide political action (Dalton 2006; Jacoby 1995). Each perspective posits a unique mechanism for linking political attitudes to political decision making, and receives strong empirical support. However, while each of these mechanisms is usually studied individually, they may all be active in the voting process in different ways. The concept of the American Creed is perhaps most consistent with the multi-dimensional framework of Moskowitz and Jenkins (2004), but the ideological-belief framework and partisanship heuristic frameworks may also provide mechanisms for organization of beliefs that are not necessarily consistent with all elements of the American Creed. Additionally the mechanism provided in the partisanship heuristic perspective may also link the American Creed to the turnout decision. Each perspective provides a mix of mechanism and alternative organization of political attitudes, thus a brief synopsis of the frameworks is necessary.

Informing the early Michigan school of mass political opinion (Campbell 1960), ideological voting is argued to depend on an ideology-belief framework in which citizens organize their political values and principles along a single liberal-conservative "ideological" dimension. This dimension, in turn, ultimately explains their 
position on political issues and their political actions (Dalton 2006; Lavine 2001; Lavine and Gschwend 2007; Saunders and Abramowitz 2004; Saunders, Abramowitz, and Williamson 2005; Teixeira 1992). The linchpin to this perspective is the role of ideology, and the deductive process that the perspective assumes. The term "ideology" is widely viewed in political science as a "set of beliefs about the role of government that shapes responses to a wide range of policy issues" (Abramowitz and Saunders 2006:177). These beliefs are best described as values or principles that provide a foundation for opinions on specific political issues (Dalton 2006). Ideological voting, however, requires high levels of political information and "ideological sophistication," and early portraits of the U.S. population did not indicate that mass political-sophistication levels where high enough to support the ideology-belief thesis (Converse 2006 [1964]). Studies of the 1948 election found that the population did not meet the "requirements commonly assumed for the successful operation of democracy," and that "in any rigorous or narrow sense the voters are not highly rational" (Berelson, Lazarsfeld, and McPhee 1986:307-310). Angus Campbell (1960) and Converse (2006 [1964]) lamented the lack of ideological voting from the citizenry, gradually developing, what would be critiqued as, an "elitist" theory of democracy (Dalton 2006). While the ideology-belief perspective may only explain a small percentage of the population's voting behavior, Abramowitz and Saunders (2006) do show that the U.S. populace is increasingly using the liberal conservative framework to organize their political opinions, although they assume a single dimensional conceptualization of ideology.

Other recent research on the structure of mass political opinion, however, argues that the deductive mechanism and single dimensional framework are too rigid (Jacoby 1995; Moskowitz and Jenkins 2004). Jacoby (1995:330) finds that only a small percentage of the population were "strongly attuned to the ideological lines of American politics" but did arrive at "ideologically consistent judgments through...intensity of feelings toward political issues." And Moskowitz and Jenkins (2004) specifically critique the ideologybelief framework on the basis that it treats attitudes and opinions that are not consistent with the ideology-belief framework as non- 
attitudes, and as such, depends on an unrealistic ideal type of ideological consistency which often sees mass opinion as insufficient. Instead, they argue for a "multi-tiered or hierarchical framework in which respondents use heuristics, backward reasoning, and other information shortcuts to organize relatively consistent political attitudes" (Moskowitz and Jenkins 2004:396). Consistent with the Abramowitz and Saunders (2006) finding, hierarchical framework studies support the finding that most people do use a liberal/conservative framework as a basic structuring principle to organize their political thinking, but do not support the deductive process leading from principles to specific opinions which the ideological-belief perspective posits (Conover and Feldman 1981; Conover and Feldman 1984; Jennings 1990; Kerlinger 1984; Moskowitz and Jenkins 2004). Rather, the hierarchical framework perspective draws from schema theory (Conover and Feldman 1981; Conover and Feldman 1984) and proposes that there are multiple general orientations organized within liberal-conservative frameworks, from which, specific issue positions and political actions are derived. The orientations are commonly referred to as social liberalism, economic liberalism, and racial liberalism (Moskowitz and Jenkins 2004).

Theoretically, the hierarchical framework solves a problem that the ideological-belief framework creates. The literature on the ideological leanings of the "working class" has long lamented the "contradictory" ideological impulses that prevent them from voting in their economic interest (Frank 2005; Lipset 1983). If there is one ideological dimension, those citizens who are socially conservative and economically progressive hold truly contradictory impulses. The separation of general orientations proposed by the hierarchical perspective theoretically solves this dilemma by arguing that the social and economic orientations are distinct, allowing, for example, individuals to be socially progressive and economically conservative without feeling an inherent contradiction or describing themselves as "moderate" (Dalton 2006; Fleishman 1988). This "contradiction" is avoided by the hierarchical framework because it allows specific political opinions be derived from multiple orientations. Thus inconsistent opinions do not necessarily represent a lack of coherence in world view, but rather shows differences in 
emphasis on different general orientations, and it is this different emphasis that is central to the influence of the American Creed on voter turnout. In short, voters may still have to decide which orientation is more important in their decision making process, but their political opinion is usually consistent with their position on the appropriate dimensions. Thus, from a hierarchical framework perspective, "inconsistent" world views occur when a citizen holds positions that are internally contradictory within a single general orientation (Dalton 2006). Most importantly, however, citizens need not be informed on all dimensions that may exist in the political world. As Dalton (2006:29) states,

In short, a complex belief system may exist within an issue public, linking issue positions to a structuring principle such as Left-Right position - even if schema are not linked across publics. Such belief structures provide voters with a method of managing information and making political judgments. Thus even if citizens are not sophisticated on all political topics, they may have logical and structured beliefs within specific domains that enable them to manage political decision making. (See also, Jacoby 1995)

At a conceptual level the American Creed fits nicely within this framework which allows individuals to place different levels of importance on different aspects of the Creed. As such, an individual could place a great deal of emphasis on one aspect of the American Creed, while failing to exercise the other elements in their voting decisions.

One of the potential problems with the hierarchical and ideology-belief frameworks is that both depend on citizens creating complex organizational structures of political opinion. The partisanship-heuristic framework, however, provides an alternative perspective arguing that people can use political cues and heuristics as information shortcuts to make political decisions (Lupia and McCubbins 1998; Sniderman, Brody, and Tetlock 1991). Group references and partisanship provide the political cues that allow individuals to make political decisions in an environment lacking political information (Converse 2006 [1964]; Dalton 2006). Both 
hierarchical and partisan-heuristic frameworks rely on satisficing mechanisms and information shortcuts, rather than democratic theory for the criteria against which they measure the consistency of mass opinion, but the partisan-heuristic thesis posits a far simpler theoretical mechanism. ${ }^{3}$ In this regard the values in the American Creed may represent the ultimate heuristic device, with individuals voting in support of candidates who are perceived to embody the Creed the best, and similarly refusing to vote in the absence of a convincing candidate. Through the use of reference groups and reference structures (i.e., left-right orientation, or party identification) individuals take into account non-political information and make surprisingly consistent political decisions (Dalton 2006; Jacoby 1995). Lavine and Gschwend (2007) find that ideological voting demands ideological ability and high motivation, while non-ideological voters rely on non-trivial character issues such as perceived leadership ability. Thus if citizens are uninformed on a specific issue, party identification, left-right orientation, or other "non-trivial" political cues act as heuristics, and provide a "central thread connecting the citizen to the political process" (Dalton 2006:30; Lavine and Gschwend 2007). The American Creed may function within such a mechanism.

\section{Hypotheses Connecting Attitudinal Frameworks and the American Creed}

While studies linking various conceptualizations of altitudinal framework to the question of turnout are scarce, each of the perspectives has significant empirical support within the literature and all, no doubt, play some role in the voting act. Taken together, these perspectives provide theoretical mechanisms that link principles to the political act, but they also provide theoretical organizing frameworks for attitudes that are inconsistent with the American Creed. This last point is especially important, as the American Creed is conceptualized as a set of cultural referents that should both constrain

\footnotetext{
${ }^{3}$ Satisficing mechanisms allow individuals to make "satisfactory" political diecisions in the absence of information or a developed ideological position (Daltion 2005).
} 
and enable political activity, and must thus have efficacy across the various mechanisms. Thus, it is plausible that the American Creed may influence voter turnout via different mechanisms for different people with different levels of political knowledge and ideological capacity. The idea that the values and principles that make up the American Creed are used in different ways is important because it is the constraining element of the American Creed, suggested by the literature concerning beliefs about equality that is the most empirically interesting. The idea that people will choose to vote when they feel strongly about an issue or value is intuitive, but an empirical finding that the American Creed can limit the efficacy of values that contradict it, and force those motivations into alternative frameworks would speak directly to its strength within the American political tradition and political culture. Here, the ideology-belief framework and partisanship heuristic framework both provide avenues for the organization of values that run counter to the Creed. If the American Creed is a nexus for political issues, attitudes, and functions with efficacy, then:

\section{Hypothesis 1:}

Voter turnout for the Republican presidential candidate should be influenced by at least one value within the American Creed that the voter supports, and values that run counter to an element of the Creed should be reframed in a manner that makes them less contradictory to the Creed.

For example, this hypothesis suggests that the social liberalism scale, utilized by Moskowitz and Jenkins (2004), should be an insignificant predictor of turnout for the Republican candidate. The reasoning behind this expectation is that if the American Creed is as wide spread and referenced as suggested in the literature, an increase in turnout due to the beliefs specifically supporting inequality of opportunity would contradict the equal opportunity element of the Creed. As it is a central component of the literature that the equal opportunity element of the American Creed is used to defend the acceptance of unequal outcomes, an outright appeal to inequality as such would be inconsistent with the expected outcome. For example, we would expect those who do not support equality to 
not vote Democratic, but they should not vote Republican for that reason, though they may do so for others, thus highlighting the importance of including abstention as a choice. On the other hand, if the American Creed is not sufficiently shared by the population or lacks the efficacy to constrain political action, as stated above, then the following results would be expected:

\section{Disconfirming Outcomes:}

Voter turnout for the Republican presidential candidate will increase due to values openly promoting inequality.

Voter turnout for the Republican presidential candidate will not be influenced by any of the values in the American Creed.

Both outcomes would indicate that the value complex that makes up the American Creed is not as salient within the population as suggested by Feldman and Zaller (1992), and does not constrain the decision making process. (See also, Kinder and Sanders 1996).

The argument that the American Creed influences voter turnout also requires evidence concerning constraints on Democratic turnout. As such:

\section{Hypothesis 2:}

Voter turnout for the Democratic presidential candidate should be influenced by at least one element of the American Creed, but values that are not consistent with the American Creed should be reorganized around alternative attitudinal frameworks.

For example, this hypothesis suggests that the social liberalism scale used by Moskowitz and Jenkins (2004) should significantly raise turnout for the Democrats, but their economic liberalism scale should have no significant effect. The reasoning behind this expectation is that if the American Creed has enough efficacy to constrain voting decisions, then a support for equality of opportunity should motivate turnout, but anti-market sentiments run counter to the American Creed and should influence turnout through another attitudinal framework. The economic liberalism scale should, however, be significantly related to Republican turnout because of 
the affinity those on the right have for market preferences, a major element of the American Creed. Once again, however, a potential lack of salience of the American Creed among voters, as discussed above, may result in a situation where the American Creed lacks efficacy. Additionally, it may be the case that the American Creed is a factor for those on the political left but not the political right, and vice versa. If this is the case, then:

\section{Disconfirming Outcomes:}

Voter turnout for the Democratic presidential candidate will increase due to values openly anti-market or anti-individual responsibility.

Voter turnout for the Democratic presidential candidate will not be influenced by any of the values in the American Creed.

Once again, if the American Creed is not salient enough throughout the population in general, then both sets of disconfirming outcomes may occur.

The American Creed centers on market preference, individual responsibility, and equal opportunity, and thus, it is qualitatively multi-dimensional. The dimensions should influence turnout in such a manner that their influence does not explicitly contradict any single value in the Creed. Summarizing my hypotheses in operational terms, findings that support my theory should be consistent with the following. The common finding in unified vote choice models is that as one becomes more Republican the probability of voting Republican increases and the probability of voting Democrat decreases proportionally. While this pattern is not expected to change in my study, unlike this pattern, the American Creed suggests that Democratic turnout should not be influenced by those with strong beliefs in government intervention in the economy, but that those with strong market-fundamentalist principles should overwhelmingly vote Republican. Similarly, the influence of the American Creed suggests that those with strong beliefs about equality should overwhelmingly support the Democrats, but a position of strong anti-egalitarian views should have no influence on Republican turnout. I now turn to a discussion of my data, variables, and methods. 


\section{Data and Methods}

I develop a model of voter turnout using a multinomial logistic regression analysis of the 1996-2004 American National Election Surveys (ANES) pre and post Presidential election samples. Aside from its contemporary relevance, I utilize the 1996-2004 ANES because research from an ideology-belief framework perspective indicates that the population represented in this time frame utilized a left-right framework to organize political attitudes more than any population in recent U.S. history (Abramowitz and Saunders 2006; Saunders and Abramowitz 2004). While political attitudes, and measures of "ideology," defined as, "values or principles that provide a foundation for opinions on specific political issues" (Abramowitz and Saunders 2006:177), are commonly used in studies of vote choice (which exclude abstention), their application to the turnout question remains under examined. This exclusion of abstention is not only problematic theoretically, but may also produce erroneous conclusions in vote choice models. Aggregated dichotomous voter turnout models also suffer from similar problems.

\section{Voter Turnout, Choice, and Multinomial Logistic Regression}

The dependent variable in this study is a trichotomous measure of voter turnout consisting of "did not vote," "voted Democrat," and "voted Republican." Although multinomial logistic regression (MNLR) is capable of analyzing more than three categories, third parties were excluded because of a lack of sufficient cases. MNLR and a trichotomous measure of voter turnout were chosen because the decision to vote and the decision of whom to vote for are closely connected. Lacy and Burden (1999) and Lacy and Monson (2002) show that variables influencing turnout do so differently based on the partisanship of the candidate, and factors that raise turnout for one candidate may lower or have no effect on turnout for the other. In dichotomous turnout models, the lumping of all voters into one category is especially problematic for the detection of effects that may raise turnout for some candidates while lowering it for others, and effects that raise or lower turnout for some candidates while 
having no influence on others (Lacy and Burden 1999). For this reason, an aggregated turnout variable that combines everyone who voted into one category is inappropriate. Multiple studies have shown that attitudes influence vote choice among voters (Abramowitz and Saunders 1998; Abramowitz and Saunders 2006; Basinger and Lavine 2005; Brooks and Manza 1997a; Brooks and Manza 1997b; Brooks and Manza 1997c; Kemmelmeier 2004; Lavine 2001; Lavine and Gschwend 2007). However, these studies exclude the choice of abstention, thus potentially providing incorrect inferences (Lacy and Burden 1999; Lacy and Monson 2002). The values in the American Creed should influence turnout for each candidate in specific ways that are not observable if those who voted are lumped together into one category or the abstention choice is excluded. As a solution, Lacy and Burden (1999) suggest a unified vote choice model that sees the voting act as a process in which the individual chooses either candidate A, candidate B or abstention. As such, a trichotomous measure of voting behavior and the application of MNLR is appropriate.

I estimate the likelihood that an individual will vote for a specific candidate rather than choosing abstention. While there is some debate concerning the choice of multinomial logit and multinomial probit (allowing correlated errors), following Dow and Endersby (2004) I chose multinomial logistic regression to avoid potential estimation problems, with which multinomial probit is susceptible. ${ }^{4}$ This choice is reflected in the functional form of the multinomial logit model:

\footnotetext{
${ }^{4}$ The inclusion of abstention creates potential problems involving the independence of irrelevant alternatives (IIA), an assumption that is built into the framework of multinomial logit models. It would be preferable to model the unified voting process as constituting the three separate alternatives (did not vote, voted Republican, and voted Democrat) with correlated errors. However, while multinomial probit models for three alternatives that do not impose the IIA assumption are available, reliable statistical software is only available for multinomial models which assume uncorrelated errors, such as the one considered here. It is important to note however, that the differences between MNL and MNP are negligible (allowing correlated errors) if utilizing a fully specified dependent variable in which all the actual categories are accounted (See Dow, J. K. and J. W. Endersby. 2004. "Multinomial probit and multinomial logit: a comparison of choice models for voting research.” Electoral Studies 23:107-122.)
} 


$$
\operatorname{Pr}\left[y_{i}=j\right]=\frac{\exp \left(X_{i} \beta_{j}\right)}{1+\sum_{j=1}^{J} \exp \left(X_{i} \beta_{j}\right)}
$$

where $\operatorname{Pr}\left[y_{i}=j\right]$ is the probability of voting for candidate $j$ in each case $i, X$ is the vector of coefficients, $\beta$ is the unknown parameters for each candidate $j$, and $J$ is the number of vote choices, including abstention. I obtain and evaluate my results through a combination of the $R$ package Zelig (Imai, King, and Lau 2007a; Imai, King, and Lau 2007b; Imai, King, and Lau 2008), and the STATA package Spost (Long and Freese 2006). Descriptive statistics for the dependent variable are shown in Table 1.

\section{Measuring Reference Structures and General Orientations}

The ANES data sets provide a large number of questions focusing on a wide array of political attitudes and opinions. Following Abramowitz and Saunders (2006), "don't knows" were recoded as the middle category for specific attitude questions, the liberalconservative orientation question and the party identification question. To fully utilize the data available, I used multiple imputation techniques provided by Amelia View to deal with missing data, following the guidelines suggested by King, Honaker, Joseph and Scheve (2001) and Honaker, King and Blackwell (2009) (See also, King, Tomz, and Wittenberg 2000). Although Honaker, King, and Blackwell (2009) recommend a minimum of five imputed datasets, I imputed ten to increase estimate precision. Using the software package Zelig, the analysis was conducted on each dataset. The mean of each coefficient and standard error were then taken, via Zelig, and the error from the process of imputing missing data was thus brought into the coefficient estimates. The complete imputation process resulted in ten datasets with an $\mathrm{N}$ of 4576. Descriptive statistics for the key independent variables can be seen in Table 1.

Perhaps the most common measure used in voting studies is liberal-conservative orientation. Liberal-conservative orientation, with a range of one to seven, is usually used in studies on voting behavior as the measure of an assumed single dimensional ideological construct (Lacy and Burden 1999; Lacy and Monson 


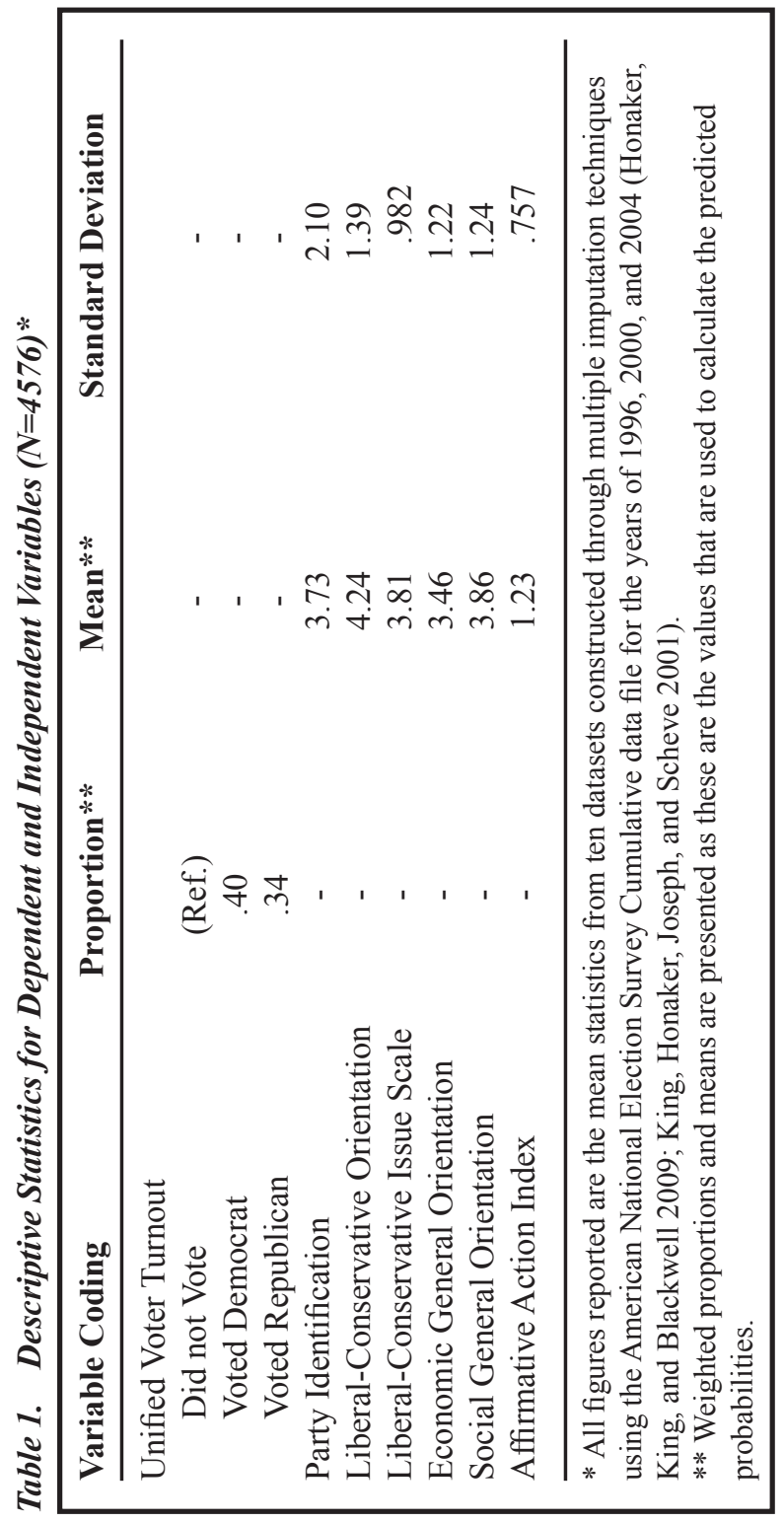


2002; Lavine 2001; Lavine and Gschwend 2007). However, Dalton (2006) actually places it within the partisan-heuristic framework along with party identification, or affiliation. Abramowitz and Saunders (2006) actually include liberal-conservative orientation in their additive scale, measuring the single liberal-conservative dimension with multiple items instead of using liberal-conservative orientation as their sole measure. While studies commonly do use the liberal-conservative orientation variable to control for "ideology," it is possible that it is actually capturing a reference structure within the partisan-heuristic framework. Consistent with Dalton (2006), I utilize liberal-conservative orientation and party identification to measure the reference structures at the center of the partisan-heuristic framework. These structures are alternative frameworks that should be used to organize political attitudes that would contradict an element of the American Creed. The inclusion of these measures allow for a more accurate and rigorous test of my hypotheses. Forcing the variance in voter turnout that is explained by political opinion into only one measure would obscure important patterns that may indicate the role of the American Creed, not to mention simply be inaccurate. Similarly, by including measures for all the attitudinal frameworks, I allow for the possibility that the framework argued to show the presence of the American Creed may not prove to be a statistically significant predictor at all.

Another such measure that is important to include is the ideology-belief framework measure. To measure the single ideological dimension at the center of the ideology-belief framework, I follow Abramowitz and Saunders (2006) and create a single additive liberal-conservative issue scale (LCI Scale). To construct the additive LCI Scale, I used 18 political attitude questions on social, economic, and racial issue topics that have been extensively used in the literature. Specifically, the economic topics covered are social security, government spending, providing jobs, healthcare, aid to the poor, welfare, and child care funding. The social questions include a four-question battery on moral and family values, abortion, legal protection against the discrimination of homosexual individuals, the role of women in the work force, homosexuals in the military, and the validity of the Bible. The two racial topics included con- 
cerned support for affirmative action. The complete questions are shown in Appendices A, B, and C. These items were recoded, if necessary, into scores from one to seven, with the most progressive score being a one and the most conservative being a seven. The scores of each item were summed, and divided by 18 , creating a scale with values from one to seven. I then further recoded the scale into seven responses. While the use of a summed scale that was not divided by 18 and retained its 126 values would have been preferable, a seven point scale was necessary for framework comparison. The extra detail contained in the large version of the scale makes it more likely to be significant in the models simply because of the larger number of categories. To account for this, and ensure a more accurate analysis, I have placed all the framework measures within 7 point scales. ${ }^{5}$

The key variables for determining the efficacy of the American Creed on voter turnout are a social general orientation, framed around moral-traditionalism and equality of opportunity, and an economic general orientation scale framed around government spending and market preference. Both the scales reference individual responsibility, and with the items available it was not possible to separate them into three separate measures that matched the exact elements of the American Creed. Following Moskowitz and Jenkins (2004) I separate the 18 items used in the LCI Scale into an economic general orientation scale (EGO Scale), a social general orientation scale (SGO Scale), and an affirmative action index. The EGO and SGO Scales were constructed using the same method as the LCI Scale and each have 7 values. Moskowitz and Jenkins (2004) also find a racial general orientation, but only two of the questions they used were available in the 1996-2004 data and alternative questions could not be located. As such, I created an affirmative action index (AFA Index) with the two available questions. The index has three values: no conservative responses, one conservative response and two conservative responses. ${ }^{6}$

\footnotetext{
${ }^{5}$ All variables consisting of additive scales achieved Cronbach's alpha scores over the commonly accepted .70 cutoff and had acceptable mean inter-item correlations as well.

${ }^{6}$ Placing the affirmative action items into an index also solved some potential
} 
Control Variables

Because a unified vote choice model combines turnout and choice it is necessary to control for the traditional indicators of both, and descriptive statistics are show in Table 2. Income, education, political interest, race/ethnicity, sex, and age have all been shown to be significant and substantively important predictors of voter turnout (Brady, Verba, and Schlozman 1995; Verba, Schlozman, and Brady 1995; Wolfinger 1980) while religion, race/ethnicity, sex, income, and occupation have been shown to be substantively significant indicators of vote choice (Brooks and Manza 1997a; Brooks and Manza 1997b; Brooks and Manza 1997c; Brooks and Manza 2004; Fiorina, Abrams, and Pope 2006; Greenberg 2005; Houtman 2003; Lipset 1983; Teixeira 1987; Teixeira 1992; Teixeira and Rogers 2000). These variables are important to include, because ideological voting, regardless of the potential role of the American Creed, is not the only type of voting that occurs (Lavine 2001; Lavine and Gschwend 2007).Political activity is limited by available resources and class interest, making occupation an important control as well (Brooks and Manza 1997a; Brooks and Manza 1997b; Brooks and Manza 1997c; Gelman and Park 2008; Verba, Schlozman, and Brady 1995). The inclusion of these controls provides a more rigorous test of the potential influence of the American Creed.

\section{Results}

\section{The American Creed and Voter Turnout}

The results of my analysis are presented in Table 3, and show results for three equations. The first equation estimates the influence of the independent variables on the choice to vote Democrat versus not voting. The second equation estimates the influence of the independent variables on voting Republican versus not voting, and the third equation estimates their influence on voting Democrat versus Republican. Due to the analysis of multiple datasets the

multi-co-linearity issues that are potential problems when so many variables are constructed from the same core set of items. 
Table 2. Descriptive Statistics for Control Variables $(N=4576)$ *

Variable Coding

Occupation

Managerial

Professional

Routine White Collar

Skilled Workers

Semi-Unskilled Workers

Non-Labor Force

Race-Ethnicity

White

Black

Other

Sex

Male

Female

Age

Std. Dev.)

.116

.154

.337

.125

.161

(ref.)

(ref.)

.141

.141

(ref.)

.545

45.6

(17.2)

Income

0-16 Percentile

(ref.)

17-33 Percentile

34-67 Percentile .303

68-95 Percentile .245

96-100 Percentile

Education

Less Than High School (ref.)

High School Diploma .405

Some College

Bachelor's Degree

.178

Advanced Degree

Political Interest

Not Much Interested

Somewhat Interested

Very Much Interested 
Table 2. (continued)

Variable Coding

Religion

Protestant

Catholic

Jewish

Other

Proportion/Mean**

Std. Dev.)

(ref.)

.262

.021

.151

Region

Non-South

(ref.)

South

Year

1996

(ref.)

2000

.385

2004

.262

* All figures reported are the mean statistics from ten datasets constructed through multiple imputation techniques using the American National Election Survey Cumulative data file for the years of 1996, 2000, and 2004 (Honaker, King, and Blackwell 2009; King, Honaker, Joseph, and Scheve 2001).

** Weighted proportions and means are presented as these are the values that are used to calculate the predicted probabilities.

common measures of model fit, such as the log-likelihood ratio and Wald test, face special technical estimation problems that are not handled in packages provided in $R$ or STATA for multinomial models (Carlin, Calati, and Royson 2008). I address this by directly assessing decreases in deviance (Gelman and Hill 2007). In all 10 datasets the full model outperforms the null model with a mean decrease in deviance of 3720 , indicating a substantially improved fit over the null model in each of the ten datasets analyzed (Gelman and Hill 2007).

By analyzing the pattern of significant coefficients in all three equations, I test the hypothesis that the set of values that make up the American Creed influence voter turnout. The measures of specific interest are the social orientation measure that indicates the level 
of belief in general equality, and the economic general orientation which indicates the level of support for market-fundamentalist principles. The effects of these variables in the model should differ from the other attitudinal variables of party identification and liberal-conservative orientation and self-identification. The specific hypothesized coefficient patterns are suggested in the operational hypotheses that follow:

\section{Hypotheses 1:}

The economic general orientation measure should be statistically significant and positive in the Republican equation, and simultaneously, the economic general orientation measure should be insignificant in the Democratic equation.

\section{Additionally:}

Hypothesis 2:

The social general orientation measure should be statistically significant and negative in the Democratic equation, and simultaneously, the social general orientation measure should be insignificant in the Republican equation.

These patterns are not expected to hold for the Democrat versus Republican equation, in which only traditional choice is measured. The theoretical reason for this expectation is that if the first two hypotheses hold, then the significant inverse relationship shown in the Democrat versus Republican equation can be interpreted as a function of differentiated turnout effects. A common finding in vote choice studies excluding abstention is that the more conservative an individual's attitudes become the more likely they are to vote Republican, and the more progressive, the more likely they are to vote Democrat (Abramowitz and Saunders 2006; Lavine 2001). However, the hypotheses associated with the American Creed suggest that the influence of values and attitudes proposed in these approaches are indeed a function of turnout patterns connected to political opinion, rather than ideological choice of candidate, which occurs after the decision to vote, has already been made. For example, a traditional vote choice finding may imply that Democratic 
voters selected the candidate because they were radically in favor of government intervention in the market. But if the American Creed hypotheses hold, then it is more plausible that this effect is a product of increased turnout of Republicans due to the market preferences aspect of the American Creed, and that the significant relationship in the traditional choice equation is the result of more Republican supporters selecting into the voting process due to a value of market preferences, not necessarily because Democrats truly support anti-market principles.

As the coefficients in Table 3 indicate, both the hypotheses are supported by the pattern of significant relationships in the analysis, and thus provide evidence that the set of values that makes up the American Creed constrains and enables voter turnout. As expected, the economic general orientation, which also emphasizes individual responsibility, is positively related to Republican turnout, but is not significant in the Democratic equation. Similarly, the social general orientation is significant and negative for the Democrats but is not significant for the Republicans. These findings suggest that the individuals tend to organize the values that motivate their turnout decision within the American Creed. Both of the orientations are significant in the Democratic versus Republican equation as expected, but a comparison of effect directions with party identification shows how these relationships must be interpreted with the inclusion of abstention.

Party identification raises and lowers turnout for both parties simultaneously, as indicated by the significant negative and positive relationships for party identification in Table 3. Graphically illustrated, this relationship looks somewhat "V" shaped above the abstention rate, as illustrated in Figure 1. As strength of party identification moves from strong Democrat to strong Republican turnout increases for the Republicans, while simultaneously decreasing for the Democrats. The result is a large number of strong partisans at the polls, and this relationship is indicated by a strong negative coefficient in the Democratic versus Republican equation that is twice the size of the coefficients in the other two equations. In this case, and with all variables with this pattern of influence, the resulting relationship indicates a high level of voting, and that as one moves 


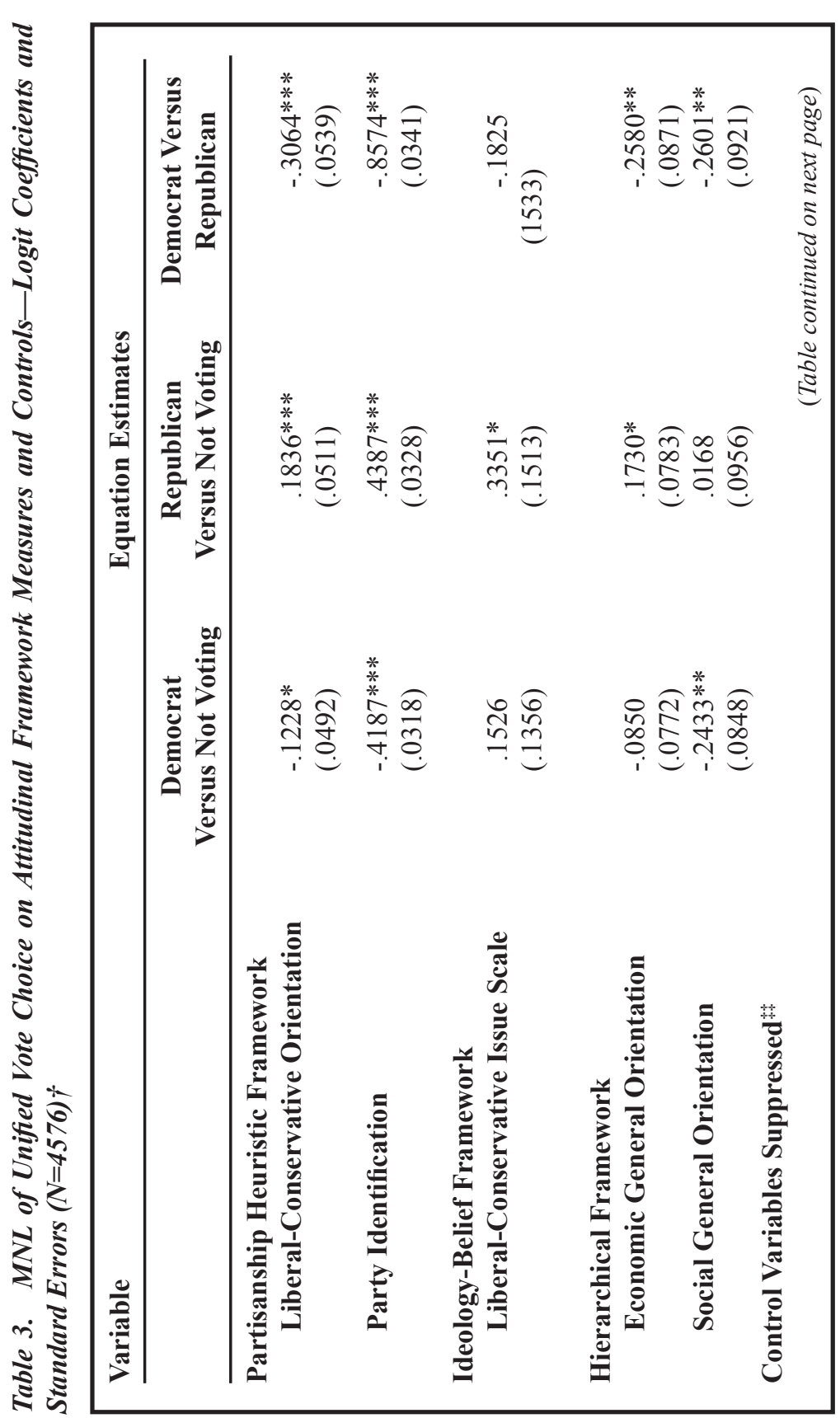




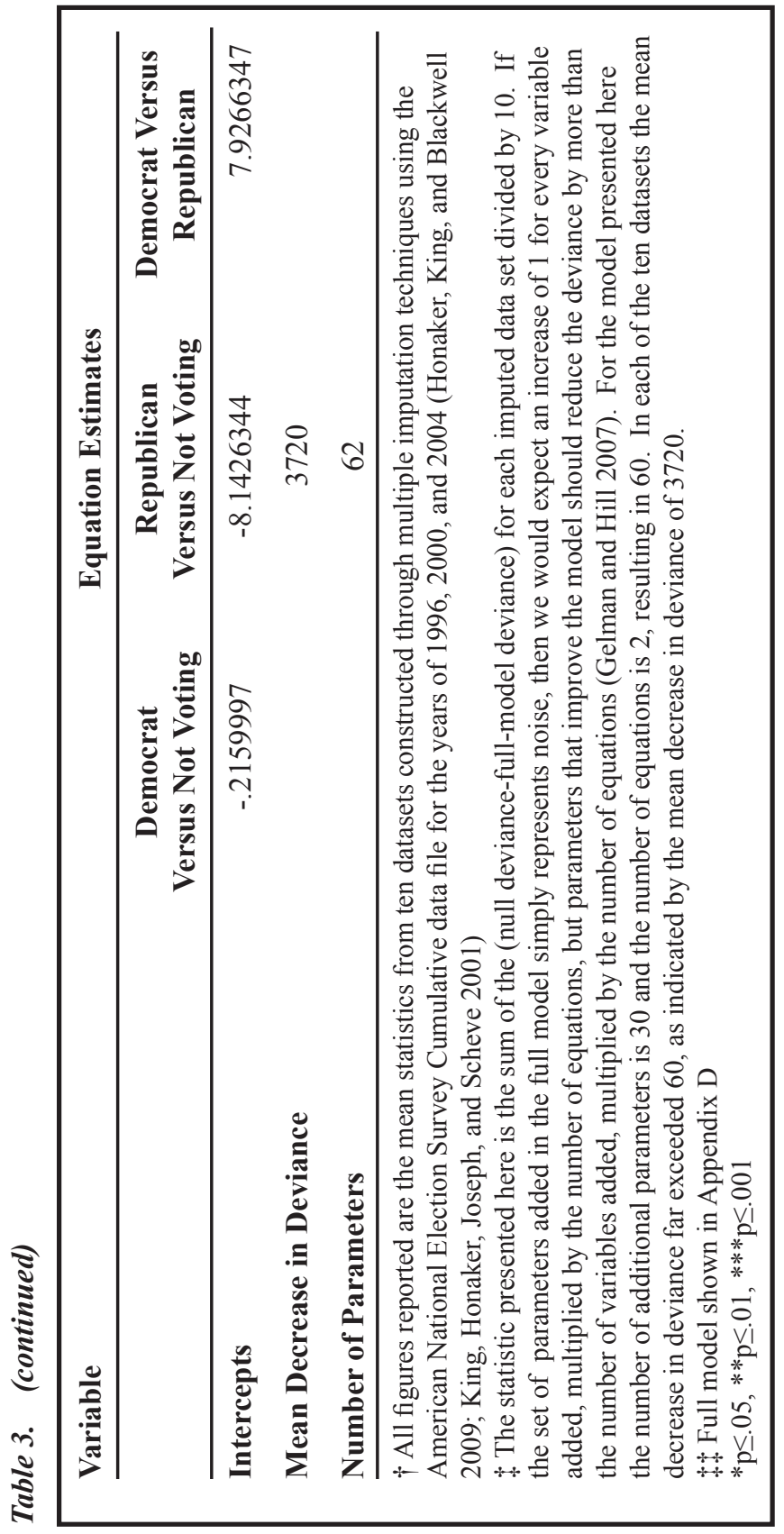




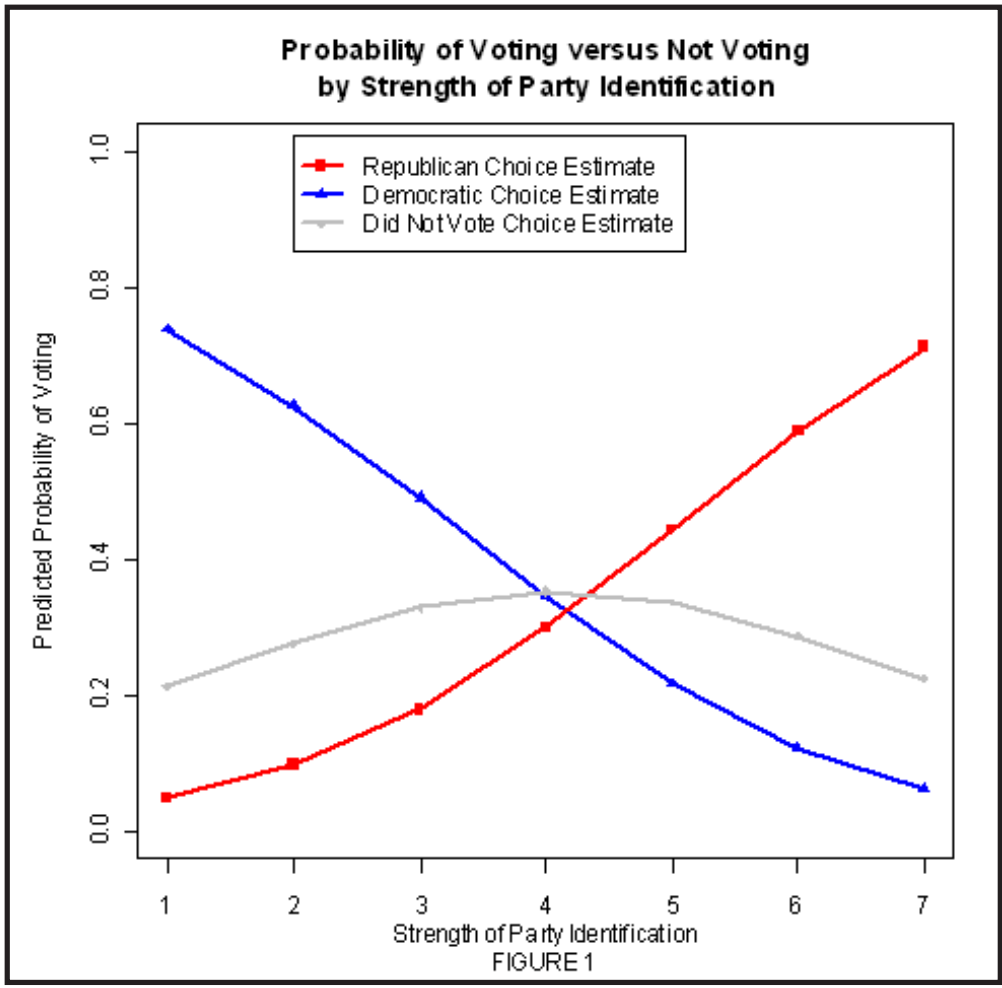

up and down the scale the probability of not voting stays relatively consistent. Attitudinal effects are commonly assumed to be of this pattern in traditional choice models that exclude abstention, and can lead to incorrect inferences. And in aggregated turnout models they are not visible because in combining the Democratic voters and Republican Voters, the effects of party identification on voter turnout statistically cancel each other out.

The exclusion of abstention would lead to an incorrect inference in the case of both general orientations because they do not influence turnout for both parties in inverse ways. The key element of the American Creed argument is that political opinion in support of the Creed should raise turnout for one candidate while having no influence on the other candidate's turnout. This is a fundamentally different type of effect than that shown with party identification. 
Calls for political action are commonly framed in support of the "traditional" American values of individual responsibility, market preference and equality of opportunity. The negative coefficient for the social general orientation in the Democratic equation provides evidence for the argument that a support of equal opportunity within the public increases turnout for Democrats. But the insignificant result in the Republican equations indicates that an open call against equality of opportunity does not increase Republican turnout. Likewise, my analysis indicates that a firm anti-market commitment is not driving turnout for the Democrats, but a defense of market preferences raises turnout for Republicans. Given the pro-market stance of both parties, even if left of the Republicans, the idea that anti-market principles are not driving Democratic turnout is not exactly counter-intuitive. The Democratic Party is by no means an equivalent to a social democratic party common in many European states. However, given the Republican embrace of the Christian right, the finding that being more conservative on the social orientation does not directly raise Republican turnout is far less intuitive. In fact, the finding that increased support for government intervention in the economy and anti-egalitarian sentiments do not directly influence the decision to vote illustrates the constraining effect that the American Creed has on turnout. Similarly, the fact that support for equality and market preferences increased turnout for the appropriate parties only, speaks to the enabling influence of the Creed.

The influence of the American Creed on turnout is substantially large. As Figure 2 shows, when holding all other factors constant at the mean, the probability of voting Republican rises from just 20 percent to about 43 percent. The exact estimate of the range of influence, from one to seven, of the economic general orientation on voter turnout for the Republicans is 26.1 percent plus or minus 17.5 percentage points.

While not nearly as large as the influence of party identification, the type of effect yields a larger electoral advantage compared to party identification. An examination of Figure 1 indicates that the size of effect for party identification is nearly identical for both parties. While comparatively smaller, the influence of the economic 


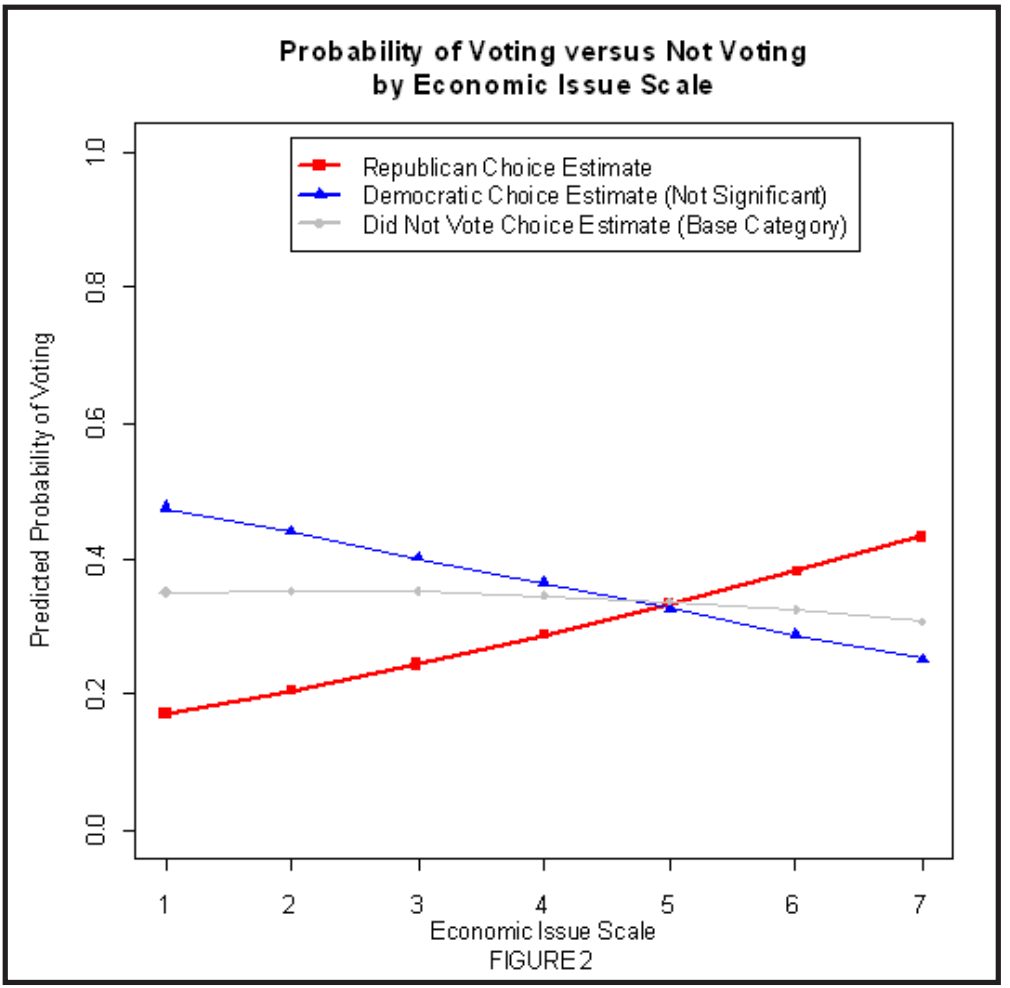

general orientation increases turnout for only the Republicans, providing an electoral edge from those with strong support for market principles. This "edge" is countered by a Democratic advantage in terms of their appeal to those who support equal opportunity. As Figure 3 shows, the influence of the social general orientation raises turnout for the Democrats, but does not have a significant influence on Republican turnout. The exact estimate of the range of influence on Democratic turnout, from one to seven, is 34 percent plus or minus 18.5 percentage points. This effect is substantial, and points to the importance of the American Creed as a central element of the political process. However, it does not mean that the issues wrapped up in the economic and social general orientations are not important to both sides of the political spectrum. 


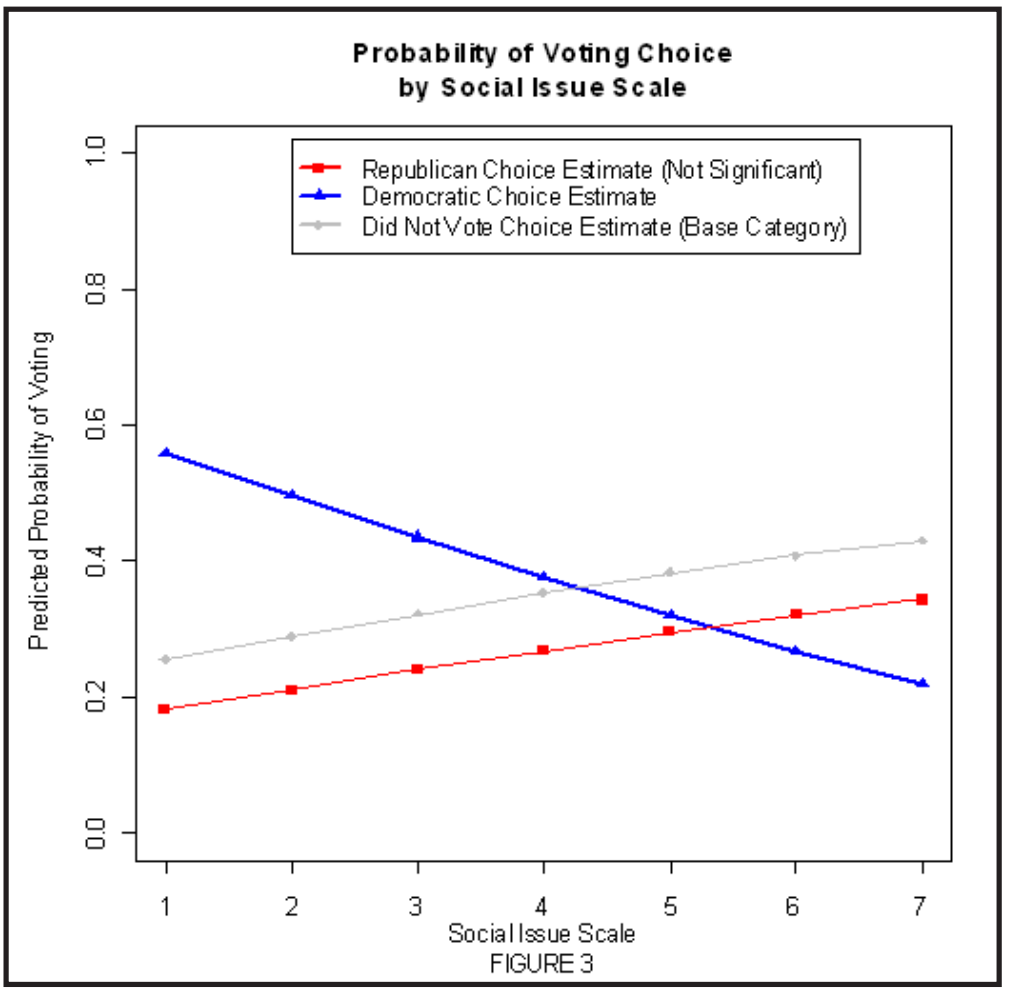

My broader findings are consistent with the argument that these issues are merely reframed, into alternative attitudinal structures; usually by framing the issue within an alternative rhetoric that seems consistent with, or directly calls upon, a separate value in the American Creed (Kinder and Sanders 1996; Santa Ana 2002). To examine which attitudinal framework/s attitude positions that were not consistent with the American Creed fell into, I estimated the model several times with various combinations of the attitudinal framework measures. In models not shown, my findings indicate that the single dimension liberal-conservative issue scale operates as a framework that allows for the acceptance of inequality to influence turnout for Republicans, and that the party identification framework seems to reframe positive support for government intervention in the economy, raising turnout for the Democrats. The influence of 
the American Creed receives additional support from the fact that all attitudinal variables had to be removed from the model except for the two general orientations for the EGO scale to be a significant indicator of Democratic turnout. Similarly, the removal of the liberal-conservative orientation measure made little change on the coefficients in either the Democratic or Republican equation on the significance levels, and the single-dimension ideological measure had to be removed to achieve a significant coefficient on the SGO scale in the Republican equation. Thus there is evidence that the frameworks suggested by the literature on mass belief systems are used differently by Republicans and Democrats.

The full model presented in Table 3 is the strongest and most theoretically grounded; however, the reader will note the absence of the affirmative action index in the model. Its absence represents yet one more piece of evidence for the central role the American Creed plays in U.S. democracy. When the affirmative action index was present, neither the LCI nor the affirmative action index were a significant predictor of turnout. However, the removal of the affirmative action index resulted in the LCI scale becoming a significant and substantively important predictor of Republican turnout that allows for the acceptance of inequality. On its own, the affirmative action index was not significant, which is consistent with the theory that political action is not driven by values that overtly contradict any element of the American Creed. A lack of support for affirmative action, can easily be interpreted as open support for inequality, however, as discussed above, support for affirmative action can also be interpreted as support for inequality. However, the removal of the affirmative action item leads to a significant LCI scale in the Republican equation indicating that it is the framework used to organize inconvenient political positions in a more palatable manner. These results thus speak to the strength of the American Creed and provide yet more evidence supporting the conclusion that the values within the American Creed both constrain and enable voter turnout. If the decision to vote were simply issues based, one would expect to find that those favoring anti-market principles would vote more often the Democrats and those favoring market principles would vote Republican. Yet my 
findings support the conclusion that the American Creed constrains the types of issues that that can directly motivate the decision to vote. Conversely it enables some to vote while forcing attitudinal reframing by others. The literature on beliefs about equality, liberalism, conservatism, and political ideology consistently show that the values of individual responsibility, equal opportunity, and market preferences are used to both promote policies supporting equality and also oppose them (Gilens 1999; Kinder and Sanders 1996; Kluegel and Smith 1986). When calls for political action are made, they are nearly always wrapped up in a discourse built around the American Creed, regardless of whether the call is emanating from the political left or right (Santa Ana 2002). Even the most radical libertarian discourses are wrapped up in the American Creed (Welsh 2008). The findings I present here extend this work to the realm of political action. My analysis indicates that there is more than rhetorical force behind the elements of the American Creed, and provides evidence that they constrain and enable turnout for both the Republicans and Democrats in distinct ways. More broadly my findings indicate that elements of the American political tradition have efficacy in the realm of political action.

\section{Conclusion}

This paper has argued that the American Creed influences voter turnout and represents more to political activity than a rhetorical framing device. The American Creed has efficacy. A support of equal opportunity increases turnout for the Democrats and a support of market preferences increases turnout for Republicans. However, political opinions that overtly contradict an element of the American Creed do not influence turnout unless reframed using alternative attitudinal frameworks. Political rhetoric in support and opposition to the same policies is framed around the American Creed (Santa Ana 2002), and it is thus difficult to promote policies that directly challenge the Creed itself. The values that influence voter turnout work in a similar manner. Republican turnout is influenced by values that accept inequality through a single-dimension liberalconservative construct. Democratic turnout is influenced by anti- 
market principles through the party identification heuristic. Support of inequality and opposition to market principles do not directly raise turnout, but support for these positions are reframed around the concepts of conservatism and political party. Put another way, they are reframed around a platform helping the free market work better for the democrats, and defending traditional values, both social and economic, for the Republicans. Where liberal-conservative orientation and party identification have inverse effects on turnout, such that increasing commitments on the conservative or Republican side results in a loss of the turnout for the other party, and vice versa, the values of the American Creed function differently. The difference between raising turnout for one party while having no effect on turnout for the other, and an effect that raises turnout for one while it lowers turnout for the other, points to important nuances in how the American Creed influences turnout. Its influence can be seen as a positive type of influence, in so far as support of its key values increases turnout, while challenging those values directly does not.

This dual nature of the American Creed may also prove to be a significant stumbling block to the deepening of U.S. democracy. While it carries with it the possibility of supporting and providing a principled call for equality, (the Civil Rights Movement articulated such a vision [Santa Ana 2002]), it also caries with it the possibility to damage democracy in the name of freedom and equal opportunity (Kinder and Sanders 1996; Santa Ana 2002). Previous findings indicate that as an element of the American political tradition, the American Creed structures political life and organizes how we think about politics in general (Feldman and Zaller 1992). The findings of this article show that the American Creed also constrains and enables political action, and thus raises concern about the prospects for the achievement of equality of outcome. A structured set of political ideas that provides a basic framework for organizing political opinion is one thing. However, a structured set of political principles that simultaneously calls for equality while justifying an acceptance of inequality that has efficacy in the realm of political action is another. Further research should continue to look into the implications of the American Creed on the health of U.S. democracy. 
On a more methodological note, the findings in this article also show the importance of accounting for abstention in studies on voting behavior, and also point to the importance of organizational frameworks that structure political attitudes. There is actually a connection between these two points. Many studies of voter behavior only control for "ideology" with a single liberalconservative item, and studies that make ideology their object of interest rarely test between multiple hypothesized frameworks. My findings speak to these two points directly. The exclusion of abstention makes the influence of market preferences and equality of opportunity seem to operate like party identification, producing what Lacy and Burden (1999) describe as "erroneous claims." Likewise the exclusion of multiple attitudinal frameworks can lead to incorrect conclusions about how the included frameworks operate. I do not wish to overstate the seriousness of problem. The common measures included in most studies to measure "ideology" and party preference, do operate in the way "ideology" is commonly assumed to function. That is, my findings do confirm that these measures do simultaneously raise turnout for one candidate while lowering it for another. But my analysis also emphasizes two important attitudinal orientations that do not function in this way, and shows the importance of also including measures for social and economic general orientations, consistent with the hierarchical framework perspective (Moskowitz and Jenkins 2004). The exclusion of the hierarchical framework measures, as well as examining voter choice and turnout separately, necessarily excludes the possibility of finding the type of effects that the American Creed has on voter turnout, and thus, be extension, choice. And as such, we miss an important element of how values influence political behavior. These issues can keep other questions off the research agenda. For example, my findings concerning the American Creed suggest that people may be spurred to political action in favor of a value or principle that is legitimated by some level of social consensus which they care about. They also call into question the idea of people voting for the lesser of "two evils." Such a premise assumes they are going to vote in the first place, and as my findings show, people do not seem to be motivated to go to the polls 
to vote against another candidate. Given the literature on beliefs about equality and my findings about the efficacy of the American Creed, individuals seem to "vote in support of a value," rather than "against a value" - although in some cases the outcome may be the similar.

Here Greenberg's (2005) discussion of the Republican strategy of a 100 percent solution provides a good example. In his analysis, he argues that effort by the Republican Party to court those further to the right and get every single one of them out to the polls, had a backlash effect of bringing out those further to left. The Greenberg (2005) thesis implies a relationship between the social general orientation and the Democratic and Republican equations that mirrors the relationship of party identification. To a large extent my findings are consistent with the outcome his thesis describes but not the mechanism. The increased turnout of the left is motivated by support for equality and a defense of the American Creed. On the other hand, the right was motivated by a defense of traditional values and norms, a major theme in conservatism (Jost, Glaser, Kruglanski, and Sulloway 2003), framed in manner such that it did not directly contradict the American Creed. In fact, as the discourse on equality illustrates, the American Creed is used to defend the oppression of certain social groups (Kinder and Sanders 1996; Sears, Sidanius, and Bobo 2000). The American Creed is thus at the center of the U.S. political scene, and its mercurial qualities provide the context of political debate and political action. As an attitudinal framework with efficacy in the realm of political action, the American Creed thus represents a potential obstacle to the passage of needed social policies. At the academic level, this efficacy in the realm of turnout demands that we take seriously the multiple frameworks that structure and organize political attitudes, how these attitudes are used in political behavior, and the choice of abstention. 
Appendix A

Social Scale Items

1. The world is always changing and we should adjust our view of moral behavior to those changes.

2. newer lifestyles are contributing to the breakdown of our society.

3. We should be more tolerant of people who choose to live according to their own moral standards, even if they are very different from our own.

4. This country would have many fewer problems if there were more emphasis on traditional family ties.

5. Some people feel that women should have an equal role with men in running business, industry, and government. Others feel that a woman's place is in the home.

6. Which of these statements comes closest to describing your feelings about the Bible?

- 1. The Bible is a book written by men and is not the word of God.

- 4. The Bible is the word of God, but not everything in it should be taken literally, word for word.

- 7. The Bible is the actual word of God and is to be taken literally, word for word.

7. Do you FAVOR or OPPOSE laws to protect homosexuals against job discrimination?

8. Do you feel strongly or not strongly that homosexuals should be allowed to serve in the United States Armed forces.

9. Which one of the opinions on this page best agrees with your view?

- 1. By law, abortion should never be permitted.

- 2. The law should permit abortion only in case of rape, incest, or when the woman's life is in danger.

- 4. Don't Know

- 6. The law should permit abortion for reasons other than rape, incest, or danger to the woman's life, but only after need for the abortion has been clearly established.

- 7. By law, a woman should always be able to obtain an abortion as a matter of personal choice. 


\section{Appendix B}

Economic Scale Items

Where would you place yourself on this scale or haven't you thought about it.

1. $1=$ Government insurance plan $/ 7=$ Private insurance plan.

2. $1=$ Government should see to jobs and standard of living $/ 7=$ Government should let each person get ahead on their own.

3. 1 = Government should provide many more services $/ 7=$ Government should provide many fewer services.

The following questions were recoded so that the conservative response was coded 7, the middle response was coded 4 , and the liberal response was coded 1 .

4. Should federal spending on Social Security be increased, decreased or kept about the same?

5. Should federal spending on Child Care be increased, decreased, or kept about the same?

6. Should federal spending on Aid to Poor People be increased, decreased, or kept about the same?

7. Should federal spending on Welfare Programs be increased, decreased, or kept about the same?

\section{Appendix C AFA Index Items}

1. Some people feel that the government in Washington should make every effort to improve the social and economic position of blacks. Others feel that the government should not make any special effort to help blacks because they should help themselves. $1=$ Government insurance plan $/ 7=$ Private insurance plan. Suppose these people are at the other end, at point 7 . And, of course, some other people have opinions somewhere in between, at points $2,3,4,5$ or 6 ).

2. Some people say that because of past discrimination blacks should be given preference in hiring and promotion. Others say that such preference in hiring and promotion of blacks is wrong because it gives blacks advantages they haven't earned. What about your opinion-are you for or against preferential hiring and promotion of blacks? 


\section{Appendix D}

MNL of Unified Vote Choice on Attitudinal

Framework Measures and Controls

Logit Coefficients and Standard Errors $(N=4576) \dagger$

\begin{tabular}{|c|c|c|c|}
\hline \multirow[t]{2}{*}{ Variable } & \multicolumn{3}{|c|}{ Equation Estimates } \\
\hline & $\begin{array}{c}\text { Democrat } \\
\text { Versus Not } \\
\text { Voting }\end{array}$ & $\begin{array}{c}\text { Republican } \\
\text { Versus Not } \\
\text { Voting }\end{array}$ & $\begin{array}{c}\text { Democrat } \\
\text { Versus } \\
\text { Republican }\end{array}$ \\
\hline \multicolumn{4}{|l|}{ Partisanship Heuristic Framework } \\
\hline Liberal-Conservative Orientation & $\begin{array}{c}-.1228^{*} \\
(.0511)\end{array}$ & $\begin{array}{c}(.0492) \\
-.3064 * * *\end{array}$ & $\begin{array}{c}.1836 * * * \\
(.0539)\end{array}$ \\
\hline Party Identification & $\begin{array}{c}-.4187 * * * \\
(.0328)\end{array}$ & $\begin{array}{c}(.0318) \\
-.8574 * * *\end{array}$ & $\begin{array}{c}.4387 * * * \\
(.0341)\end{array}$ \\
\hline \multicolumn{4}{|l|}{ Ideology-Belief Framework } \\
\hline Liberal-Conservative Issue Scale & $\begin{array}{l}.1526 \\
(.1513)\end{array}$ & $\begin{array}{l}(.1356) \\
-.1825\end{array}$ & $\begin{array}{l}.3351^{*} \\
(1533)\end{array}$ \\
\hline \multicolumn{4}{|l|}{ Hierarchical Framework } \\
\hline Economic General Orientation & $\begin{array}{c}-.0850 \\
(.0783)\end{array}$ & $\begin{array}{c}(.0772) \\
-.2580^{* *}\end{array}$ & $\begin{array}{l}.1730^{*} \\
(.0871)\end{array}$ \\
\hline Social General Orientation & $\begin{array}{c}-.2433 * * \\
(.0956)\end{array}$ & $\begin{array}{c}(.0848) \\
-.2601 * *\end{array}$ & $\begin{array}{l}.0168 \\
(.0921)\end{array}$ \\
\hline \multicolumn{4}{|l|}{ Occupation: } \\
\hline Non-Fulltime-Labor & (ref.) & (ref.) & (ref.) \\
\hline Managerial & $\begin{array}{l}.1553 \\
(.2486)\end{array}$ & $\begin{array}{l}(.2144) \\
.1643\end{array}$ & $\begin{array}{l}-.0090 \\
(.2592)\end{array}$ \\
\hline Professionals & $\begin{array}{l}.4445^{*} \\
(.2335)\end{array}$ & $\begin{array}{l}(.2098) \\
.3489\end{array}$ & $\begin{array}{l}.0956 \\
(.2475)\end{array}$ \\
\hline Routine White Collar Workers & $\begin{array}{l}.0595 \\
(.2004)\end{array}$ & $\begin{array}{l}(.1673) \\
-.0026\end{array}$ & $\begin{array}{c}.0621 \\
(.2087)\end{array}$ \\
\hline Skilled Workers & $\begin{array}{l}.0285 \\
(.2492)\end{array}$ & $\begin{array}{c}(.2153) \\
.0639\end{array}$ & $\begin{array}{c}-.0354 \\
(.2661)\end{array}$ \\
\hline Semi/Unskilled Workers & $\begin{array}{l}-.0120 \\
(.2542)\end{array}$ & $\begin{array}{l}(.2010) \\
-.0961\end{array}$ & $\begin{array}{l}.0841 \\
(.2757)\end{array}$ \\
\hline Education: & & & \\
\hline Less Than High School & (ref.) & (ref.) & (ref.) \\
\hline High School & $\begin{array}{l}.3532 * \\
(.1986)\end{array}$ & $\begin{array}{c}(.1455) \\
-.5782 * *\end{array}$ & $\begin{array}{c}.9314 * * * \\
(.2142)\end{array}$ \\
\hline Some College & $\begin{array}{c}.6796 * * * \\
(.2241)\end{array}$ & $\begin{array}{l}(.1838) \\
-.5374^{*}\end{array}$ & $\begin{array}{c}1.2170^{* * *} \\
(.2435)\end{array}$ \\
\hline Bachelor's Degree & $\begin{array}{c}1.145 * * * \\
(.2524)\end{array}$ & $\begin{array}{l}(.1965) \\
-.4728\end{array}$ & $\begin{array}{c}1.6179 * * * \\
2585)\end{array}$ \\
\hline Advanced Degree & $\begin{array}{c}1.2220 * * * \\
(.3473)\end{array}$ & $\begin{array}{l}(.3021) \\
-.6622 *\end{array}$ & $\begin{array}{c}1.884 * * * \\
(.3232)\end{array}$ \\
\hline
\end{tabular}

(Table continued on next page) 
Social Thought \& Research

\begin{tabular}{|c|c|c|c|}
\hline \multirow[t]{2}{*}{ Variable } & \multicolumn{3}{|c|}{ Equation Estimates } \\
\hline & $\begin{array}{c}\text { Democrat } \\
\text { Versus Not } \\
\text { Voting }\end{array}$ & $\begin{array}{c}\text { Republican } \\
\text { Versus Not } \\
\text { Voting }\end{array}$ & $\begin{array}{c}\text { Democrat } \\
\text { Versus } \\
\text { Republican }\end{array}$ \\
\hline \multicolumn{4}{|l|}{ Race and Ethnicity: } \\
\hline White & (ref.) & (ref.) & (ref.) \\
\hline Black & $\begin{array}{l}.5260 * * \\
(.2263)\end{array}$ & $\begin{array}{c}(.1596 \\
1.203 * * *\end{array}$ & $\begin{array}{c}-.6774 * * \\
(.2251)\end{array}$ \\
\hline Other & $\begin{array}{l}-.0747 \\
(.1553)\end{array}$ & $\begin{array}{c}(.1349) \\
.2525\end{array}$ & $\begin{array}{c}-.3272^{*} \\
(.1740)\end{array}$ \\
\hline \multicolumn{4}{|l|}{ Religion: } \\
\hline Protestant & (ref.) & (ref.) & (ref.) \\
\hline Catholic & $\begin{array}{c}.1475 \\
(.1392)\end{array}$ & $\begin{array}{l}(.1208) \\
-.1803\end{array}$ & $\begin{array}{l}.3278^{*} \\
(.1348)\end{array}$ \\
\hline Jewish & $\begin{array}{l}.1590 \\
(.5822)\end{array}$ & $\begin{array}{c}(.3613) \\
.7662\end{array}$ & $\begin{array}{l}-.6072 \\
(.4931)\end{array}$ \\
\hline Other & $\begin{array}{l}-.3134^{*} \\
(.1589)\end{array}$ & $\begin{array}{l}(.1416) \\
-.0288\end{array}$ & $\begin{array}{l}-.2846 \\
(.1589)\end{array}$ \\
\hline \multicolumn{4}{|l|}{ Interest in Politics: } \\
\hline Not Much Interested & (ref.) & (ref.) & (ref.) \\
\hline Somewhat Interested & $\begin{array}{c}1.0567 * * * \\
.1296)\end{array}$ & $\begin{array}{c}(.1175) \\
.1492\end{array}$ & $\begin{array}{c}.9075^{* * *} \\
(.1436)\end{array}$ \\
\hline Very Interested & $\begin{array}{c}1.888^{* * *} \\
(.1721)\end{array}$ & $\begin{array}{c}(.1547) \\
.3078\end{array}$ & $\begin{array}{c}1.5807 * * * \\
(.1737)\end{array}$ \\
\hline \multicolumn{4}{|l|}{ Income: } \\
\hline 0-16 ${ }^{\text {th }}$ Percentile & (ref.) & (ref.) & (ref.) \\
\hline $17^{\text {th }}-33^{\text {rd }}$ Percentile & $\begin{array}{c}.2722 \\
(.1823)\end{array}$ & $\begin{array}{c}(.1699) \\
.0833\end{array}$ & $\begin{array}{c}.1888 \\
(.2034)\end{array}$ \\
\hline $34^{\text {th }}-67^{\text {th }}$ Percentile & $\begin{array}{l}.4955^{* *} \\
(.1829)\end{array}$ & $\begin{array}{c}(.1547) \\
.1107\end{array}$ & $\begin{array}{l}.3848^{*} \\
(.1903)\end{array}$ \\
\hline $68^{\text {th }}-95^{\text {th }}$ Percentile & $\begin{array}{c}.8473 * * * \\
(.1951)\end{array}$ & $\begin{array}{c}(.1705) \\
.0969\end{array}$ & $\begin{array}{c}.7504 * * * \\
(.2010)\end{array}$ \\
\hline $96^{\text {th }}-100^{\text {th }}$ Percentile & $\begin{array}{c}.4914 \\
(.2897)\end{array}$ & $\begin{array}{l}(.3094) \\
-.2052\end{array}$ & $\begin{array}{l}.6966^{*} \\
.2897\end{array}$ \\
\hline \multicolumn{4}{|l|}{ Sex: } \\
\hline Male & (ref.) & (ref.) & (ref.) \\
\hline Female & $\begin{array}{c}.0988 \\
(.1382)\end{array}$ & $\begin{array}{l}(.1126) \\
-.0036\end{array}$ & $\begin{array}{c}.1024 \\
(.1292)\end{array}$ \\
\hline Age & $\begin{array}{c}.0214 * * * \\
(.0034)\end{array}$ & $\begin{array}{c}(.0031) \\
.0027\end{array}$ & $\begin{array}{c}.0187 * * * \\
(.0034)\end{array}$ \\
\hline \multicolumn{4}{|l|}{ Region: } \\
\hline Non-South & (ref.) & (ref.) & (ref.) \\
\hline South & $\begin{array}{c}-.3909 * * * \\
(.1333)\end{array}$ & $\begin{array}{c}(.1053) \\
-.3916^{* * *}\end{array}$ & $\begin{array}{l}-.0007 \\
(.1334)\end{array}$ \\
\hline \multicolumn{4}{|l|}{ Year: } \\
\hline 1996 & (ref.) & (ref.) & (ref.) \\
\hline 2000 & $\begin{array}{l}-.0558 \\
(.1255)\end{array}$ & $\begin{array}{c}(.1100) \\
-.5340 * * *\end{array}$ & $\begin{array}{c}.4782 * * * \\
(.1306)\end{array}$ \\
\hline 2004 & $\begin{array}{l}-.2190 \\
(.1496)\end{array}$ & $\begin{array}{c}(.1311) \\
-.8888^{* * *}\end{array}$ & $\begin{array}{c}.6698 * * * \\
(.1516)\end{array}$ \\
\hline
\end{tabular}




\begin{tabular}{|c|c|c|c|}
\hline Intercepts & -.2159997 & -8.1426344 & 7.9266347 \\
\hline Mean Decrease in Deviance & & 3720 & \\
\hline Number of Parameters & & 62 & \\
\hline
\end{tabular}

$\dagger$ All figures reported are the mean statistics from ten datasets constructed through multiple imputation techniques using the American National Election Survey Cumulative data file for the years of 1996, 2000, and 2004 (Honaker, King, and Blackwell 2009; King, Honaker, Joseph, and Scheve 2001)

\$ The statistic presented here is the sum of the (null deviance-full-model deviance) for each imputed data set divided by 10 . If a set of variables added to the model simply representes noise, then we would expect an increase of 1 for every variable added, multiplied by the number of equations, but parameters that improve the model should reduce the deviance by more than the number of parameters added, multiplied by the number of equations (Gelman and Hill 2007). For the model presented here the number of additional variables is 30 and the number of equations is 2 , resulting in 60 . In each of the ten datasets the mean decrease in deviance far exceeded 60 . as indicated by the mean decrease in deviance of 3720 .

${ }^{*} \mathrm{p} \leq .05, * * \mathrm{p} \leq .01, * * * \mathrm{p} \leq .001$

\section{References}

Abramowitz, A. I. and K. L. Saunders. 1998. "Ideological realignment in the US electorate." Journal of Politics 60:634-652.

- 2006. "Exploring the bases of partisanship in the American electorate: Social identity vs. ideology." Political Research Quarterly 59:175-187.

Altemeyer, Bob. 1996. The authoritarian specter. Cambridge, MA: Harvard University Press.

Barker, D. C. and J. D. Tinnick. 2006. "Competing visions of parental roles and ideological constraint." American Political Science Review 100:249-263.

Basinger, S. J. and H. Lavine. 2005. "Ambivalence, information, and electoral choice." American Political Science Review 99:169-184.

Berelson, Bernard, Paul Felix Lazarsfeld, and William N. McPhee. 1986. Voting: a study of opinion formation in a presidential campaign. Chicago: University of Chicago Press.

Brady, H. E., S. Verba, and K. L. Schlozman. 1995. "Beyond SES-A Resource Model of Political Participation." American Political Science Review 89:271-294.

Brooks, C. and J. Manza. 1997a. "Class politics and political change in the United States, 1952-1992." Social Forces 76:379-408. - 1997b. "The social and ideological bases of middle-class political realignment in the United States, 1972 to 1992." American Sociological Review 62:191-208. 
1997c. "Social cleavages and political alignments: US presidential elections, 1960 to 1992." American Sociological Review 62:937-946.

_ 2004. "A great divide? Religion and political change in US national elections, 1972-2000.” Sociological Quarterly 45:421-450.

Campbell, Angus. 1960. The American voter. New York: Wiley.

Carlin, J. B., J. C. Calati, and P. Royson. 2008. "A new Framework for Managing and Analyzing Multiply Imputed data in Stata." The Stata Journal 8:49:67.

Conover, P. J. and S. Feldman. 1981. "The Origins and Meaning of LiberalConservative Self-identifications." American Journal of Political Science 25:617-645.

— 1984. "How People Organize the Political World-A Schematic Model." American Journal of Political Science 28:95-126.

Converse, P. E. 2006 [1964]. "The nature of belief systems in mass publics (1964) (Reprinted from Ideology and its Discontents)." Critical Review 18:1-74.

Dalton, Russell J. 2006. Citizen politics: public opinion and political parties in advanced industrial democracies. Washington, DC: CQ Press.

Davis, Kingsley and Wilbert E. Moore. 2006 [1945]. "Some Principles of Stratification." Pp. 1-5 in Inequality, edited by D. B. Grusky and S. Szelenyi. Boulder, CO: Westview Press.

Dow, J. K. and J. W. Endersby. 2004. "Multinomial probit and multinomial logit: a comparison of choice models for voting research." Electoral Studies 23:107-122.

Feldman, S. and J. Zaller. 1992. "The Political-Culture of AmbivalenceIdeological Responses to the Welfare-State." American Journal of Political Science 36:268-307.

Fiorina, Morris P., Samuel J. Abrams, and Jeremy Pope. 2006. Culture war?: the myth of a polarized America. New York: Pearson Longman.

Fleishman, John A. 1988. "Attitude Organization in the General Public: Evidence for a Bidimensional Structure." Social Forces 67:159-184.

Frank, Thomas. 2005. What's the matter with Kansas?: how conservatives won the heart of America. New York: Henry Holt.

Gelman, Andrew and Jennifer Hill. 2007. Data analysis using regression and multilevel/hierarchical models. Cambridge; New York: Cambridge University Press.

Gelman, Andrew and David Park. 2008. Red state, blue state, rich state, poor state: why Americans vote the way they do. Princeton: Princeton University Press.

Gilens, Martin. 1999. Why Americans hate welfare: race, media, and the politics of antipoverty policy. Chicago: University of Chicago Press. 
Greenberg, Stanley B. 2005. The two Americas: our current political deadlock and how to break it. New York: Thomas Dunne Books/St. Martin's Griffin.

Honaker, James, Gary King, and Matthew Blackwell. 2009. Amelia II: A Program for Missing Data.

Houtman, Dick. 2003. "Lipset and "working-class" authoritarianism." The American Sociologist. 34:85-103.

Imai, Kosuke, Gary King, and Olivia Lau. 2007a. "mlogit: Multinomial Logistic Regression for Dependent Variables with Unordered Categorical Variables." in Zelig: Everyone's Statistical Software, edited by K. Imai, G. King, and O. Lau.

—. 2007b. "Zelig: Everyone's Statistical Software."

—. 2008. "Toward a Common Framework for Statistical Analysis and Development." Journal of Computational and Graphical Statistics 17:892-913.

Jacoby, W. G. 1995. "The Structure of Ideological Thinking in the American Electorate." American Journal of Political Science 39:314-335.

Jacoby, William G. 2000. "Issue Framing and Public Opinion on Government Spending." American Journal of Political Science 44:750-767.

Jennings, M. Kent. 1990. Continuities in political action: a longitudinal study of political orientations in three western democracies. Berlin; New York: W. de Gruyter.

Jost, J. T. 2006. "The end of the end of ideology." American Psychologist 61:651-670.

Jost, J. T., J. Glaser, A. W. Kruglanski, and F. J. Sulloway. 2003. "Political conservatism as motivated social cognition." Psychological Bulletin 129:339-375.

Kemmelmeier, M. 2004. "Authoritarianism and candidate support in the US presidential elections of 1996 and 2000." Journal of Social Psychology 144:218-221.

Kerlinger, Fred N. 1984. Liberalism and conservatism: the nature and structure of social attitudes. Hillsdale, NJ: L. Erlbaum.

Kinder, Donald R. and Lynn M. Sanders. 1996. Divided by color: racial politics and democratic ideals. Chicago: University of Chicago Press.

King, G., J. Honaker, A. Joseph, and K. Scheve. 2001. "Analyzing incomplete political science data: An alternative algorithm for multiple imputation." American Political Science Review 95:49-69.

King, G., M. Tomz, and J. Wittenberg. 2000. "Making the most of statistical analyses: Improving interpretation and presentation." American Journal of Political Science 44:347-361. 
Kluegel, James R. and Eliot R. Smith. 1986. Beliefs about inequality: Americans'views of what is and what ought to be. New York: A. de Gruyter.

Lacy, D. and B. C. Burden. 1999. "The vote-stealing and turnout effects of Ross Perot in the 1992 US presidential election.” American Journal of Political Science 43:233-255.

Lacy, D. and Q. Monson. 2002. "The origins and impact of votes for thirdparty candidates: A case study of the 1998 Minnesota gubernatorial election." Political Research Quarterly 55:409-437.

Laitin, David D. and Wildavsky Aaron. 1988. "Political Culture and Political Preferences." The American Political Science Review 82:589-597.

Lavine, H. 2001. "The electoral consequences of ambivalence toward presidential candidates." American Journal of Political Science 45:915-929.

Lavine, H. and T. Gschwend. 2007. "Issues, party and character: The moderating role of ideological thinking on candidate evaluation." British Journal of Political Science 37:139-163.

Lavine, H., C. J. Thomsen, M. P. Zanna, and E. Borgida. 1998. "On the primacy of affect in the determination of attitudes and behavior: The moderating role of affective-cognitive ambivalence." Journal of Experimental Social Psychology 34:398-421.

Lipset, Seymour Martin. 1983. Political man: the social bases of politics. London: Heinemann.

-1996. American exceptionalism: a double-edged sword. New York: W.W. Norton.

Long, J. Scott and Jeremy Freese. 2006. Regression models for categorical dependent variables using Stata. College Station, TX: Stata Press.

Lupia, Arthur and Mathew D. McCubbins. 1998. The democratic dilemma: can citizens learn what they need to know? Cambridge, U.K.; New York: Cambridge University Press.

Moskowitz, A. N. and J. C. Jenkins. 2004. "Structuring political opinions: Attitude consistency and democratic competence among the US mass public." Sociological Quarterly 45:395-419.

Myrdal, Gunnar, Richard Mauritz Edvard Sterner, and Arnold Marshall Rose. 1944. An American dilemma; the Negro problem and modern democracy. New York, London: Harper \& brothers.

Santa Ana, Otto. 2002. Brown tide rising: metaphors of Latinos in contemporary American public discourse. Austin: University of Texas Press.

Saunders, K. L. and A. I. Abramowitz. 2004. "Ideological realignment and active partisans in the American electorate." American Politics Research 32:285-309. 
Saunders, K. L., A. I. Abramowitz, and J. Williamson. 2005. “A new kind of balancing act: Electoral certainty and ticket-splitting in the 1996 and 2000 elections." Political Research Quarterly 58:69-78.

Sears, David O., Jim Sidanius, and Lawrence Bobo. 2000. Racialized politics: the debate about racism in America. Chicago: University of Chicago Press.

Sidanius, Jim, Felicia Pratto, and Lawrence Bobo. 1996. "Racism, conservatism, Affirmative Action, and intellectual sophistication: A matter of principled conservatism or group dominance?" Journal of Personality and Social Psychology 70:476-490.

Sniderman, Paul M., Richard A. Brody, and Philip E. Tetlock. 1991. Reasoning and choice: explorations in political psychology. Cambridge [England]; New York: Cambridge University Press.

Teixeira, Ruy A. 1987. Why Americans don't vote: turnout decline in the United States, 1960-1984. New York: Greenwood Press.

— 1992. The disappearing American voter. Washington, DC: Brookings Institution.

Teixeira, Ruy A. and Joel Rogers. 2000. America's forgotten majority: why the white working class still matters. New York: Basic Books.

University of Michigan. Survey Research Center. and Angus Campbell. 1960. The American voter. New York,: Wiley.

Verba, Sidney, Kay Lehman Schlozman, and Henry E. Brady. 1995. Voice and equality: civic voluntarism in American politics. Cambridge, Mass.: Harvard University Press.

Welsh, John F. 2008. After multiculturalism: the politics of race and the dialectics of liberty. Lanham, MD: Lexington Books.

Wolfinger, Raymond E. 1980. Who votes? New Haven: Yale University Press. 